University of Nebraska - Lincoln

DigitalCommons@University of Nebraska - Lincoln

2014

\title{
Evaluation of grain distillers dried yeast as a fish meal substitute in practical-type diets of juvenile rainbow trout, Oncorhynchus mykiss
}

\author{
Blake S. Hauptman \\ USFWS, Bozeman, MT \\ Frederic T. Barrows \\ USDA-ARS, Bozeman, MT, Rick.Barrows@ars.usda.gov \\ Stephanie S. Block \\ ADM Research, Decatur, IL \\ T. Gibson Gaylord \\ USFWS, Bozeman, MT \\ John A. Paterson \\ Montana State University - Bozeman
}

See next page for additional authors

Follow this and additional works at: https://digitalcommons.unl.edu/usfwspubs

Part of the Aquaculture and Fisheries Commons

Hauptman, Blake S.; Barrows, Frederic T.; Block, Stephanie S.; Gaylord, T. Gibson; Paterson, John A.; Rawles, Steven D.; and Sealy, Wendy M., "Evaluation of grain distillers dried yeast as a fish meal substitute in practical-type diets of juvenile rainbow trout, Oncorhynchus mykiss" (2014). US Fish \& Wildlife Publications. 460.

https://digitalcommons.unl.edu/usfwspubs/460

This Article is brought to you for free and open access by the US Fish \& Wildlife Service at DigitalCommons@University of Nebraska - Lincoln. It has been accepted for inclusion in US Fish \& Wildlife Publications by an authorized administrator of DigitalCommons@University of Nebraska - Lincoln. 


\section{Authors}

Blake S. Hauptman, Frederic T. Barrows, Stephanie S. Block, T. Gibson Gaylord, John A. Paterson, Steven D. Rawles, and Wendy M. Sealy 


\title{
Evaluation of grain distillers dried yeast as a fish meal substitute in practical-type diets of juvenile rainbow trout, Oncorhynchus mykiss
}

\author{
Blake S. Hauptman a,b, Frederic T. Barrows ${ }^{\text {c }}$, Stephanie S. Block ${ }^{\text {d }}$, T. Gibson Gaylord a , John A. Paterson b, \\ Steven D. Rawles ${ }^{\mathrm{e}}$, Wendy.M. Sealey ${ }^{\mathrm{a}, *}$ \\ ${ }^{a}$ US Fish and Wildlife Service, Bozeman Fish Technology Center, Bozeman, MT 59715, USA \\ b Montana State University, Department of Animal and Range Sciences, Bozeman, MT 59715, USA \\ c USDA-ARS, Trout Grains Project, Bozeman Fish Technology Center, Bozeman, MT 59715, USA \\ d ADM Research, 1001 N Brush College Road, Decatur, IL 62521, USA \\ e USDA-ARS, Harry K. Dupree Stuttgart National Aquaculture Research Center, 130 East, Stuttgart, AR 72160, USA
}

\section{A R T I C L E I N F O}

\section{Article history:}

Received 22 November 2013

Received in revised form 18 March 2014

Accepted 20 March 2014

Available online 3 April 2014

\section{Keywords:}

Alternative protein

Rainbow trout

Grain distillers dried yeast

Fish nutrition

\begin{abstract}
A B S T R A C T
Grain distillers dried yeast (GDDY) is a single-cell protein obtained as a co-product during the production of fuel ethanol that may have potential as a protein replacement for rainbow trout. The goal of this study was to examine the suitability of GDDY as a replacement for fish meal on a digestible protein basis in rainbow trout diets. An in-vivo digestibility study was performed to determine the nutrient availability of GDDY. Subsequently, a control diet containing $42 \%$ digestible protein and $20 \%$ lipid was formulated to replace fish meal protein with GDDY protein at eight different levels $(0,25,37.5,50,62.5,75,87.5$, and $100 \%)$. Diets were fed to juvenile rainbow trout stocked into four replicate tanks per dietary treatment ( $30 \mathrm{fish} / \mathrm{tank}$ ) and fed twice daily for nine weeks. High GDDY inclusion rates significantly altered rainbow trout growth and feed conversion but not feed intake. There were no significant differences in production performance in fish fed the 25\% GDDY and 37.5\% GDDY diets when compared to fish fed the control diet, but further dietary fish meal replacement generally decreased fish performance. Further research is warranted to determine why fish performance decreased with higher inclusion levels of GDDY in spite of similar feed intake among levels.
\end{abstract}

Published by Elsevier B.V.

\section{Introduction}

In the past few years, the aquaculture industry has seen an intensive rise in feed costs, particularly for carnivorous species due to competition for limited supplies of fish meal (Tacon and Metian, 2008). This has resulted in renewed vigor for development and examination of alternative feed ingredients, specifically protein sources that may be more sustainable and less expensive (Gatlin et al., 2007). The utilization of by-products from the alternative fuel industries also has been of increasing interest due to potential for increased future volumes of these products (Barrows et al., 2008). Specifically, two feed grade byproducts have been investigated and these include distillers dried grains with solubles (DDGS), the grain-based by-product and the spent yeast fraction, grain distillers dried yeast (GDDY). Although, recent studies have address the suitability of DDGS inclusion in rainbow trout diets (Barnes et al., 2012a,b; Cheng and Hardy, 2004; Øverland et al., 2013), the suitability of GDDY for rainbow trout has not been addressed.

\footnotetext{
* Corresponding author.

E-mail address: Wendy_Sealey@fws.gov (W.M. Sealey).
}

Research on the effects of yeast products in the diets of rainbow trout has focused on their role as immune-stimulants rather than macro-nutrient sources at inclusion rates that were predominantly less than $5 \%$ of diet (Gatesoupe, 2007). However, selected single-cell proteins have shown potential as dietary protein sources. Rumsey et al. (1991a) determined the digestibility of brewer's dried yeast (BDY) processed by different methods in rainbow trout and then measured growth performance when BDY was included as the primary protein source in the diet. When BDY was processed into a protein isolate, protein digestibility increased to $87.3 \%$ compared to $63.2 \%$ for the nonprocessed intact BDY. In a subsequent study, Rumsey et al. (1991b) found that BDY could be included at up to $25 \%$ of a fish meal-free diet without decreases in weight gain or FCR when casein was the primary protein source. When BDY was included above $25 \%$, however, the fish exhibited poor growth and FCR. Similarly, Martin et al. (1993) found that yeast biomass Candida utilis could effectively replace up to $35 \%$ of dietary fish meal without significant decreases in growth performance of rainbow trout. Limited replacement (25\%) of fish meal by another commercial yeast product, NuPro ${ }^{\mathrm{TM}}$ (Alltech Inc., Lexington, KY, USA), has also been reported in cobia diets (Lunger et al., 2006). Lunger et al (2006) were able to increase NuPro ${ }^{\mathrm{TM}}$ inclusion levels in cobia diets 


$$
\mathrm{ADCN}_{\text {ingredient }}=\left\{(\mathrm{a}+\mathrm{b}) \mathrm{ADCN}_{\mathrm{t}}-(\mathrm{a}) \mathrm{ADCN}_{\mathrm{r}}\right\} \mathrm{b}^{-1}
$$

where,

$\mathrm{ADCN}_{\text {ingredient }}$ apparent digestibility coefficient of the nutrient in the test ingredient

$\mathrm{ADCN}_{\mathrm{t}}$ apparent digestibility coefficients of the nutrient in the test diets

$\mathrm{ADCN}_{\mathrm{r}}$ apparent digestibility coefficients of the nutrient in the reference diet

a $\quad(1-p) \times$ nutrient content of the reference diet

b $\quad \mathrm{p} \times$ nutrient content of the test ingredient

$\mathrm{p} \quad$ proportion of test ingredient in the test diet.

\subsection{Feeding trial}

\subsubsection{Study design}

A 9-week feeding trial with juvenile rainbow trout was conducted to examine the effects of replacing fish meal protein on a digestible protein basis with increasing levels of GDDY protein $(0,25,37.5,50,62.5,75$, 87.5 , and $100 \%$ replacement; Table 2 ) on growth performance, nutrient retention and diet digestibility. All treatments were randomly assigned to four replicate tanks each, making tank the experimental unit. Test diets were formulated to contain $42 \%$ digestible protein and $20 \%$ crude lipid and were balanced for available lysine (3.82), methionine (1.30), and threonine (2.14), as well as total phosphorus (1.5). Nutrient targets were formulated on a digestible nutrient basis utilizing data from trial 1 .

\subsubsection{Diet manufacturing}

Diets were manufactured by cooking extrusion (DNDL-44, Buhler AG, Uzwil, Switzerland) with an 18-s exposure to an average of $127^{\circ} \mathrm{C}$ in the sixth extruder barrel section. The die plate was water cooled to an average temperature of $60{ }^{\circ} \mathrm{C}$. Pressure at the die head was varied from 200 to $400 \mathrm{psi}$, depending on test diet. Pellets of $4 \mathrm{~mm}$ were produced then dried in a pulse-bed drier (Buhler AG, Uzwil, Switzerland) for $25 \mathrm{~min}$ at $102{ }^{\circ} \mathrm{C}$ with a 10 -minute cooling period. Final moisture levels of each diet were less than $10 \%$. Fish oil was top-coated after drying and cooling using a vacuum coater (A.J. Mixing, Ontario, Canada).

\subsubsection{Pellet durability testing}

Pellet durability was assessed using a NHP100 portable pellet durability tester (Holmen, Norfolk, UK). Briefly, approximately $50 \mathrm{~g}$ of pellets were loaded into the test chamber which cascades the pellets in an air stream causing them to collide with each other and the perforated hard surfaces within the test chamber at a test cycle of $60 \mathrm{~s}$. After the test cycle, sample pellets are ejected from the tester for manual weighing. The pellet durability index (PDI) is the difference between pellet weight before and after the test expressed as a percentage of initial weight. PDIs were determined on duplicate pellet samples from each diet within seven days of diet manufacture.

Table 2

Composition of test diets containing grain distillers dried yeast (GDDY) to replace fish meal fed to juvenile rainbow trout ( $22.1 \pm 0.3 \mathrm{~g}$ ) for 9 weeks.

\begin{tabular}{|c|c|c|c|c|c|c|c|c|}
\hline \multirow[b]{2}{*}{ Ingredients } & \multicolumn{8}{|l|}{ Diets $^{\mathrm{a}}$} \\
\hline & $0 \%$ & $25 \%$ & $37.5 \%$ & $50 \%$ & $62.5 \%$ & $75 \%$ & $87.5 \%$ & $100 \%$ \\
\hline Grain distillers dried yeast ${ }^{\mathrm{b}}$ & 0.0 & 7.6 & 11.2 & 14.9 & 18.6 & 22.3 & 25.9 & 29.6 \\
\hline Menhaden fish meal, special select ${ }^{c}$ & 25.0 & 18.8 & 15.6 & 12.5 & 9.4 & 6.3 & 3.1 & 0.0 \\
\hline Corn protein concentrate ${ }^{\mathrm{d}}$ & 5.0 & 5.0 & 5.0 & 5.0 & 5.0 & 5.0 & 5.0 & 5.0 \\
\hline Blood meal $^{\mathrm{e}}$ & 3.0 & 3.0 & 3.0 & 3.0 & 3.0 & 3.0 & 3.0 & 3.0 \\
\hline Soy bean meal, solvent extracted de-hulled ${ }^{\mathrm{C}}$ & 15.0 & 15.0 & 15.0 & 15.0 & 15.0 & 15.0 & 15.0 & 15.0 \\
\hline Poultry by-product meal, pet food grade ${ }^{c}$ & 16.3 & 16.3 & 16.3 & 16.3 & 16.3 & 16.3 & 16.3 & 16.3 \\
\hline Wheat flour ${ }^{\mathrm{e}}$ & 14.5 & 10.8 & 9.5 & 8.3 & 6.9 & 5.7 & 4.4 & 3.1 \\
\hline Fish oil, menhaden ${ }^{c}$ & 14.6 & 14.7 & 14.8 & 14.9 & 15.0 & 15.1 & 15.2 & 15.3 \\
\hline Lecithin $^{c}$ & 1.0 & 1.0 & 1.0 & 1.0 & 1.0 & 1.0 & 1.0 & 1.0 \\
\hline Stay-C $35^{\mathrm{f}}$ & 0.2 & 0.2 & 0.2 & 0.2 & 0.2 & 0.2 & 0.2 & 0.2 \\
\hline Vitamin premix ${ }^{g}$ & 1.0 & 1.0 & 1.0 & 1.0 & 1.0 & 1.0 & 1.0 & 1.0 \\
\hline Trace mineral premix ${ }^{\mathrm{h}}$ & 0.1 & 0.1 & 0.1 & 0.1 & 0.1 & 0.1 & 0.1 & 0.1 \\
\hline Sodium chloride & 0.0 & 0.3 & 0.3 & 0.3 & 0.3 & 0.3 & 0.3 & 0.3 \\
\hline Magnesium oxide & 0.0 & 0.1 & 0.1 & 0.1 & 0.1 & 0.1 & 0.1 & 0.1 \\
\hline Potassium chloride & 0.0 & 0.6 & 0.6 & 0.6 & 0.6 & 0.6 & 0.6 & 0.6 \\
\hline Dicalcium phosphate & 0.0 & 0.9 & 1.4 & 1.9 & 2.4 & 2.8 & 3.3 & 3.8 \\
\hline Choline chloride & 1.0 & 1.0 & 1.0 & 1.0 & 1.0 & 1.0 & 1.0 & 1.0 \\
\hline DL-Met ${ }^{\mathrm{i}}$ & 0.4 & 0.5 & 0.5 & 0.5 & 0.5 & 0.6 & 0.6 & 0.6 \\
\hline Lysine $\mathrm{HCl}^{\mathrm{i}}$ & 1.9 & 2.1 & 2.2 & 2.2 & 2.3 & 2.4 & 2.5 & 2.6 \\
\hline Threonine $^{\mathrm{i}}$ & 0.4 & 0.5 & 0.5 & 0.6 & 0.6 & 0.6 & 0.7 & 0.7 \\
\hline Taurine $^{\mathrm{i}}$ & 0.5 & 0.5 & 0.5 & 0.5 & 0.5 & 0.5 & 0.5 & 0.5 \\
\hline Yttrium oxide & 0.1 & 0.1 & 0.1 & 0.1 & 0.1 & 0.1 & 0.1 & 0.1 \\
\hline \multicolumn{9}{|l|}{ Analyzed composition ${ }^{\mathrm{j}}$} \\
\hline$\%$ crude protein & 50.8 & 49.8 & 49.5 & 49.2 & 49.1 & 48.7 & 48.4 & 48.5 \\
\hline$\%$ lipid & 18.0 & 18.9 & 19.2 & 18.7 & 18.9 & 19.5 & 20.1 & 19.4 \\
\hline Gross energy kcal/g & 5533 & 5606 & 5629 & 5633 & 5679 & 5727 & 5762 & 5804 \\
\hline$\%$ moisture & 2.3 & 2.4 & 2.8 & 2.9 & 3.4 & 3.6 & 3.9 & 4.2 \\
\hline
\end{tabular}

a Percent of fish meal replaced by GDDY on a digestible protein basis.

b Archer Daniels Midland (Decatur, IL, USA).

c Nelson \& Sons Inc. (Murray, UT, USA).

d Gavilon LLC (Omaha, NE, USA).

e MGP Ingredients, Inc. (Atchison, KS, USA).

f Rovimix Stay-C 35, DSM Products.

g Contributed per kg of diet: vitamin A (as retinol palmitate), 30,000 IU; vitamin $\mathrm{D}_{3}, 2160 \mathrm{IU}$; vitamin E (as DL-\%-tocopheryl-acetate), $1590 \mathrm{IU}$; niacin, 990 mg; calcium pantothenate, $480 \mathrm{mg}$; riboflavin, $240 \mathrm{mg}$; thiamin mononitrate, $150 \mathrm{mg}$; pyridoxine hydrochloride, $135 \mathrm{mg}$; menadione sodium bisulfate, $75 \mathrm{mg}$; folacin, $39 \mathrm{mg}$; biotin, $3 \mathrm{mg}$; vitamin $\mathrm{B}_{12}$, 90 $\mu$ g.

h Contributed in $\mathrm{mg} / \mathrm{kg}$ of diet: zinc, 37; manganese, 10; iodine, 5; copper, 3; selenium, 0.4.

i L-Lysine HCL 99\% feed grade, DL-methionine 99\% feed grade, threonine L-threonine 98.5\% feed grade, taurine ADM (Decatur, IL, USA).

j Means of two replicate samples per diet on a dry matter basis. 


\subsubsection{Fish culture}

Rainbow trout from a single lot were obtained from a commercial producer (Troutlodge, Inc., Sumner, WA, USA) and cultured at the Bozeman Fish Technology Center, Bozeman, MT. Fish were stocked at 30 fish/tank (22.1 $\pm 0.26 \mathrm{~g}$, mean \pm SD initial weight). Lighting was maintained on a 13:11 h diurnal cycle. Fish were acclimated to tanks for one week prior to the beginning of feeding trial. Diets were randomly assigned to four tanks per dietary treatment in 32, $200 \mathrm{~L}$ tanks. Tanks were configured in a partial recirculating system with biofiltration, solids removal and UV treatment of the water. Approximately $25 \%$ makeup water was added to the system daily, and water temperature was maintained at $14{ }^{\circ} \mathrm{C}$. Fish were fed to apparent satiation twice a day, six days a week for nine weeks and feed intake was determined by weighing buckets before and after feeding. Apparent satiation was defined as all the feed the fish will consume in a 30 min period.

\subsubsection{Sampling and index calculations}

Ten fish from the initial population were sacrificed for determination of initial whole-body proximate composition. During the growth trial, fish were weighed every two weeks for the determination of FCR, feed intake and weight gain. At the conclusion of the study, three fish from each tank were randomly selected for whole body composition and three additional fish were dissected for determination of hepatosomatic index (HSI), visceral somatic index (VSI), and filet ratio (FR).

Hepatosomatic Index $(\mathrm{HSI})=\frac{(\text { Liver mass }(\mathrm{g}) * 100)}{\text { fish } \operatorname{mass}(\mathrm{g})}$

Viscerosomatic Index $(\mathrm{VSI})=\frac{(\text { viscera mass }(\mathrm{g}) * 100)}{\text { fish mass }(\mathrm{g})}$

Filet Ratio $(\mathrm{FR})=\frac{(\text { filet mass with ribs }(\mathrm{g}) * 100)}{\text { fish mass }(\mathrm{g})}$

Energy retention efficiency(ERE)

$=$ energy gain in fish $(\mathrm{g}) /$ energy intake $(\mathrm{g}) * 100$

Protein retention efficiency(PRE)

$=$ protein gain in $\mathrm{fish}(\mathrm{g}) /$ protein intake $(\mathrm{g}) * 100$

\subsubsection{Statistical analysis}

Response data were subjected to analysis of variance (ANOVA) and regression analysis using the software programs PROC GLM and PROC REG, respectively, in SAS version 9.1 (SAS Institute Inc., Cary, NC, USA). Additionally, weight gain and FCR data were $\log _{e}$ transformed $\left(\operatorname{Ln} Y_{T}\right.$ ) using the relationship $\operatorname{Ln} \mathrm{Y}_{\mathrm{T}}=\operatorname{Ln}(1+\mathrm{Y})$ and subjected to spline regression analysis using the SAS software program PROC NONLIN according to Freund and Littell (2000). Following ANOVA, differences among means were separated using the Tukey-Kramer procedure for pairwise comparisons (Kramer, 1956; Tukey, 1953) when treatment effects were considered significant at $P \leq 0.05$. All regressions were considered significant when both $\mathrm{R}^{2} \geq 0.20$ and $P \leq 0.05$.

Table 3

Chemical analysis (\% dry weight) and apparent digestibility coefficients (ADCs) of nutrients in grain distillers dried yeast (GDDY) and menhaden fish meal.

\begin{tabular}{lccccc}
\hline & \multicolumn{2}{l}{ Chemical analysis } & & \multicolumn{2}{l}{ ADCs } \\
\cline { 2 - 3 } Item, \% & GDDY & Fish meal $^{\mathrm{a}}$ & & GDDY & Fish meal $^{\mathrm{a}}$ \\
\hline Dry matter & 91.5 & 92.7 & & 65.4 & 77.7 \\
Crude protein & 52.0 & 68.0 & & 97.6 & 85.9 \\
Crude fat & 3.9 & 8.0 & & 100.0 & 92.7 \\
Energy (kcal/g) & 5945.0 & 4709.3 & & 69.7 & 94.8 \\
Phosphorus & 0.7 & 3.6 & & 80.7 & 43.8
\end{tabular}

a Mean of values in USDA-ARS/USFWS Digestibility Database for menhaden fish meal, Special Select ${ }^{\mathrm{TM}}$ (Barrows et al., 2011).

\section{Results}

\subsection{In vivo digestibility}

The analyzed proximate composition of GDDY as compared to fish meal averages was lower in total protein content and lower concentrations of individual amino acids, specifically, the three most common limiting amino acids for rainbow trout, lysine, methionine, and threonine (Table 3; Table 4). Grain distillers dried yeast ADCs for protein, dry matter (DM), fat, and energy were 97.6, 65.4, 100.0, and 69.7\%, respectively (Table 3 ). Grain distillers dried yeast AACs for methionine, lysine, threonine, and the sum of amino acids were $88.1,75.5,70.8$, and $80.7 \%$, respectively (Table 4 ).

\subsection{Feeding trial}

\subsubsection{Diet composition and pellet durability}

Analyzed dietary macronutrient composition reflected formulation targets (Table 2). Pellet durability was significantly altered by increasing GDDY inclusion such that pellet loss increased quadratically ( $\mathrm{y}=$ $\left.0.002 x^{2}+0.042 x+5.82 ; R^{2}=0.982\right)$ as function of fish meal replacement (Fig. 1).

\subsubsection{Growth performance and body condition indices}

Increasing inclusion of GDDY in rainbow trout diets significantly reduced growth and increased feed conversion (Table 5); no effect on feed intake was observed (Table 5; Fig. 4). No significant differences occurred in weight gain and feed conversion ratio of fish fed the $25 \%$ and $37.5 \%$ FM replacement diets as compared to fish fed the control diet when analyzed by ANOVA. These results were confirmed by spline regression that showed a highly significant $(P<0.0001)$ breakpoint for Ln weight gain when Ln FM replacement level equaled 3.715, i.e., 41\% FM replacement or $12 \%$ GDDY in the diet (Fig. 2) and when Ln FM replacement level equaled 3.544, i.e., 34\% FM replacement or 10\% GDDY in the diet for Ln FCR (Fig. 3). There was a linear increase $\left(P=0.010 ; \mathrm{R}^{2}=\right.$ $0.404)$ in VSI with increasing replacement of FM with GDDY in the diet (Table 5; Fig. 5), but no break point could be fit with spline regression analysis. However, FR and HSI were unrelated to GDDY level in the diet (Table 5).

\subsubsection{Proximate composition, hematocrit, and retention efficiencies}

Replacement of fish meal with GDDY had no significant effect on whole body proximate composition; lipid levels ranged from 11.8 to

Table 4

Amino acids (\% dry weight) and their apparent availability coefficients (AACs) in rainbow trout in grain distillers dried yeast (GDDY) and menhaden fish meal.

\begin{tabular}{lccccc}
\hline & \multicolumn{2}{l}{ Chemical analysis } & & \multicolumn{2}{l}{ AACs } \\
\cline { 2 - 3 } \cline { 5 - 6 } Item, \% & GDDY & Fish meal & & GDDY & Fish meal $^{\text {a }}$ \\
\hline Alanine & 3.7 & 4.7 & & 82.4 & 89.4 \\
Arginine & 2.2 & 4.8 & & 80.8 & 91.4 \\
Aspartic acid & 3.8 & 6.6 & & 72.1 & 87.6 \\
Glutamine & 7.7 & 9.7 & & 83.6 & 95.3 \\
Glysine & 1.8 & 5.2 & & 78.7 & 75.0 \\
Histidine & 1.0 & 1.5 & & 78.9 & 92.1 \\
Isoleucine & 2.0 & 2.9 & & 79.0 & 95.2 \\
Leucine & 5.9 & 5.2 & & 84.0 & 97.2 \\
Lysine & 2.3 & 4.6 & & 75.5 & 92.9 \\
Methionine & 1.0 & 1.7 & & 88.1 & 94.9 \\
Phenylalanine & 2.8 & 2.9 & & 89.4 & 89.5 \\
Proline & 3.4 & 3.6 & & 83.0 & 84.8 \\
Serine & 2.7 & 3.2 & & 76.2 & 91.6 \\
Threonine & 2.2 & 3.3 & & 70.8 & 92.3 \\
Tyrosine & 2.5 & 2.4 & 85.0 & 95.9 \\
Valine & 2.2 & 3.7 & 79.2 & 93.4 \\
Sum AA & 48.0 & 66.1 & 80.7 & 90.9
\end{tabular}

a Mean of values in USDA-ARS/USFWS Digestibility Database for menhaden fish meal, Special Select ${ }^{\mathrm{TM}}$ (Barrows et al., 2011). 


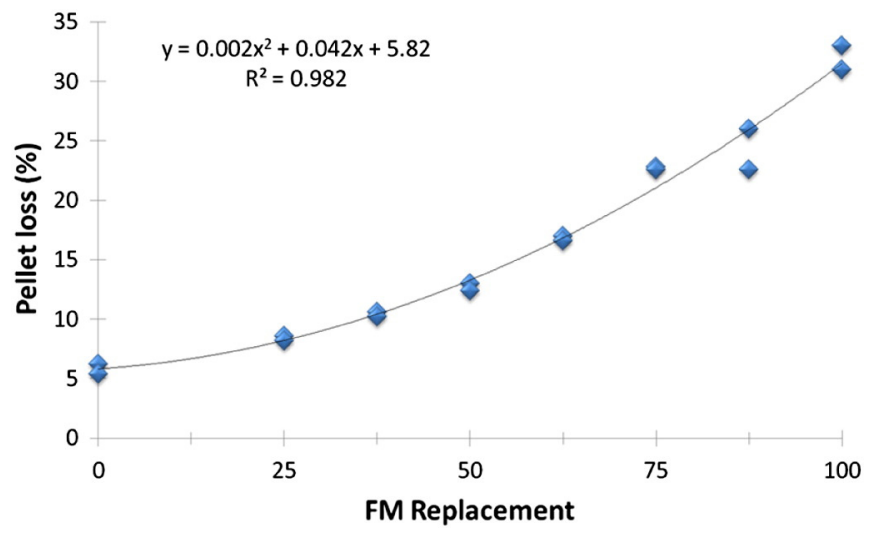

Fig. 1. Pellet durability of diets with increasing levels of FM replacement by GDDY in the diet.

$13.5 \%$ and whole body protein ranged from 16.1 to $17.1 \%$ (Table 6 ). Hematocrit ranged from 39 to $48 \%$ with no discernible dietary effects. No dietary effects were noted for protein and energy retention efficiencies which ranged between 32.9 to $38.2 \%$ and 39.6 to $45.4 \%$, respectively (Table 6).

\subsubsection{Diet digestibility post-feeding}

No significant effects of diet on lipid or energy ADCs were observed (Table 7). Dietary lipid ADC ranged from 83.6 to 87.9 whereas energy ADC ranged from 77.9 to 81.2. In contrast, significant increases in protein and phosphorus digestibility coefficients were observed with increasing GDDY inclusion. Protein ADCs were relatively high and increased slightly from 84.9 to 88.1 whereas phosphorus ADCs were low and ranged from 31.4 to 51.1 .

\section{Discussion}

Grain distillers dried yeast showed improved availability of protein, fat and phosphorus when compared to the average fish meal ADCs found in USDA ARS/USFWS Digestibility Database (Barrows et al., 2011). The protein digestibility of GDDY was higher than the average fish meals analyzed by Gaylord et al. (2008) and was comparable to some of the plant concentrate ingredients tested in that study. Grain distillers dried yeast protein digestibility was similar to anchovy fish

Table 5

Growth performance and body indices of juvenile rainbow trout $(22.1 \pm 0.3 \mathrm{~g})$ fed test diets containing grain distillers dried yeast (GDDY) for 9 weeks.

\begin{tabular}{|c|c|c|c|c|c|c|}
\hline \multirow[t]{3}{*}{$\operatorname{Diet}^{\mathrm{c}}$} & \multicolumn{3}{|c|}{ Growth performance $^{\mathrm{a}}$} & \multicolumn{3}{|c|}{ Body indices $^{\mathrm{b}}$} \\
\hline & Weight gain ${ }^{\mathrm{d}}$ & $\mathrm{FCR}^{\mathrm{e}}$ & Feed intake ${ }^{\mathrm{f}}$ & $\mathrm{VSI}^{\mathrm{g}}$ & $\mathrm{FR}^{\mathrm{h}}$ & $\mathrm{HSI}^{\mathrm{i}}$ \\
\hline & \multicolumn{2}{|l|}{$\%$} & $\%$ bw day ${ }^{-1}$ & $\%$ & $\%$ & $\%$ \\
\hline $0 \%$ & $570^{\mathrm{a}}$ & $0.87^{\mathrm{c}}$ & 2.5 & $12.2^{\mathrm{b}}$ & 53.8 & 1.3 \\
\hline $25 \%$ & $564^{\mathrm{a}}$ & $0.93^{\mathrm{b}, \mathrm{c}}$ & 2.7 & $12.3^{\mathrm{b}}$ & 51.4 & 1.3 \\
\hline $37.5 \%$ & $564^{\mathrm{a}}$ & $0.94^{\mathrm{b}, \mathrm{c}}$ & 2.7 & $12.3^{\mathrm{b}}$ & 54.1 & 1.2 \\
\hline $50 \%$ & $522^{\mathrm{b}}$ & $1.03^{\mathrm{a}, \mathrm{b}}$ & 2.9 & $12.8^{\mathrm{a}, \mathrm{b}}$ & 53.3 & 1.2 \\
\hline $62.5 \%$ & $520^{\mathrm{b}}$ & $0.96^{\mathrm{b}, \mathrm{c}}$ & 2.7 & $14.3^{\mathrm{a}}$ & 53.0 & 1.4 \\
\hline $75 \%$ & $491^{\mathrm{c}}$ & $1.01^{\mathrm{a}, \mathrm{b}}$ & 2.8 & $14.2^{\mathrm{a}}$ & 50.5 & 1.3 \\
\hline $87 \%$ & $470^{c, d}$ & $1.04^{\mathrm{a}, \mathrm{b}}$ & 2.9 & $14.0^{\mathrm{a}}$ & 51.7 & 1.4 \\
\hline $100 \%$ & $444^{\mathrm{d}}$ & $1.10^{\mathrm{a}}$ & 3.0 & $14.2^{\mathrm{a}}$ & 50.2 & 1.3 \\
\hline Pooled SE & 8.83 & 0.04 & 0.11 & 0.52 & 1.99 & 0.08 \\
\hline $\operatorname{Pr}>\mathrm{F}$ & $<0.001$ & 0.017 & 0.153 & 0.010 & 0.773 & 0.356 \\
\hline
\end{tabular}

a Means of four replicate tanks of fish (30 fish/tank).

b Mean determinations in three fish/tank from $N=4$ replicate tanks/diet.

c Percent of fish meal replaced by GDDY on a digestible protein basis.

${ }^{\mathrm{d}}$ Weight gain $(\%)=($ final weight - initial weight $) * 100$ / initial weight

e FCR, feed conversion ratio $=\mathrm{g}$ dry feed consumed $/ \mathrm{g}$ weight gained.

${ }^{\mathrm{f}}$ Feed intake $(\%)=\mathrm{g}$ dry feed consumed/average fish biomass $(\mathrm{g}) /$ culture days $* 100$.

$\mathrm{g}$ VSI, visceral somatic index $(\%)=$ viscera mass $\times 100 /$ fish mass.

h FR, filet ratio $(\%)=$ filet with rib mass $* 100 /$ fish mass.

${ }^{\mathrm{i}}$ HSI, hepatosomatic index $(\%)=$ liver mass $\times 100 /$ fish mass.

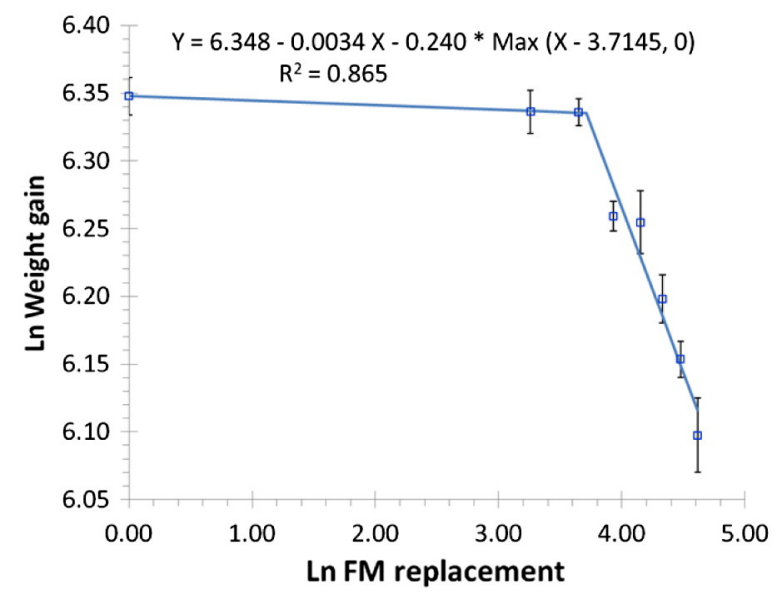

Fig. 2. Spline regression of Ln weight gain in rainbow trout with respect to Ln FM replacement level in the diet

meal (97\%), soy protein concentrate (99\%) and wheat gluten meal (100\%). GDDY apparent digestibility coefficients for protein were higher than all other ingredients that were reported by Gaylord et al. (2008). GDDY results show improved protein digestibility when compared to brewer's dried yeast as reported by Rumsey et al. (1991a). Lower digestibility coefficients for dry matter and energy were observed for GDDY compared to fish meal most likely due to the relatively high nitrogen free extract content of the ingredient.

In contrast, GDDY amino acid availabilities (AACs) were lower than the fish meals reported by Gaylord et al. (2010). Among the five fish meals tested, the AACs of the essential amino acids (EAAs) for rainbow trout were relatively high, ranging from $89 \%$ to $101 \%$, and the availability coefficients for the sum of amino acids were no less than $92 \%$ (Gaylord et al., 2010). GDDY AACs for the EAAs tested ranged from $79 \%$ to $89 \%$ with the AAC of the sum of amino acids totaling $81 \%$. GDDY amino acid availability was similar to that of other alternative proteins reported by Gaylord et al. (2010) including poultry byproduct meal (84\%) and rice protein concentrate (86\%).

It is possible that the lower AACs for specific amino acids in the digestibility trial may, in part, explain the decreased growth performance of rainbow trout in the feeding trials. The current feeding trial results are similar to the findings of Martin et al. (1993) who demonstrated that yeast biomass included at $20 \%$ of the diet could successfully replace up to $35 \%$ of dietary fish meal for rainbow trout. The data from the current study are consistent with other reports utilizing single-cell proteins in diets for sunshine bass and cobia (Gause and Trushenski, 2011a;

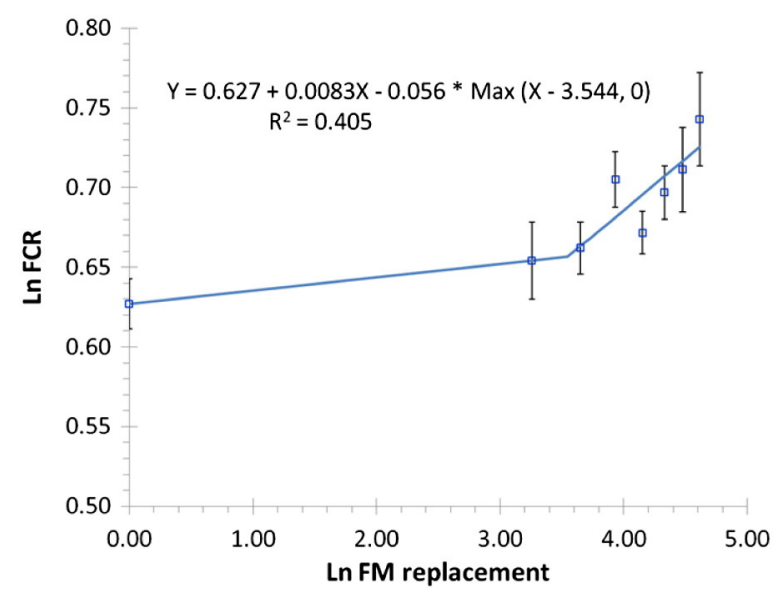

Fig. 3. Spline regression of Ln FCR in rainbow trout with respect to Ln FM replacement level in the diet. 


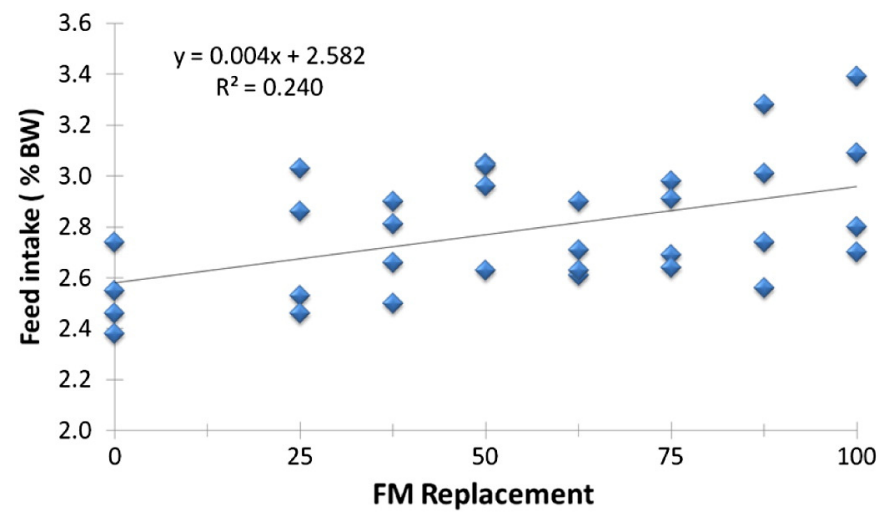

Fig. 4. Feed intake (\% BW) of fish fed diets with increasing levels of FM replacement by GDDY in the diet GDDY.

Lunger et al., 2006) where total replacement of fish meal was unattainable. However, the failure of these single-cell protein ingredients as complete fish meal replacers was postulated by those authors to be an issue with palatability. Lunger et al. (2006), although not quantifying feed intake, observed uneaten feed remaining in the tanks when feeding to a percentage of fish biomass. Gause and Trushenski (2011a, 2011b) proposed a palatability issue with increasing ethanol yeast inclusion. In those studies, decreased intakes were observed in diets with highest inclusions of yeast product relative to their control (fish meal) diets. Results from the current study, however, demonstrated that there was no relationship between palatability, as measured by relative intake, and the performance of rainbow trout fed each of the experimental diets.

The effects of dietary GDDY inclusion on rainbow trout condition indices and proximate composition measurements are similar to existing literature regarding observed effects of alternative proteins (Gause and Trushenski, 2011a; Snyder et al., 2012). Gause and Trushenski (2011a) reported increased visceral fat deposits and increased whole body lipid composition in fish fed higher inclusion levels of GDDY, which the authors attributed to reduced accumulation of lean muscle mass and a relative increase in adiposity as fish attempted to compensate for amino acid imbalances. Snyder et al. (2012) also reported higher intraperitoneal fat in fish fed isolated soy protein-based diets containing excess branched chain amino acids (BCAAs) and suggested that BCAAs may have caused overeating as fish tried to meet EAA requirements. Although, whole body composition was not altered by GDDY inclusion in the current study, the increased consumption and increased VSI found in fish fed higher levels of GDDY during the current study does lend additional credence to the hypothesis of an increasing amino acid deficiency with increasing GDDY replacement of FM in the diet.

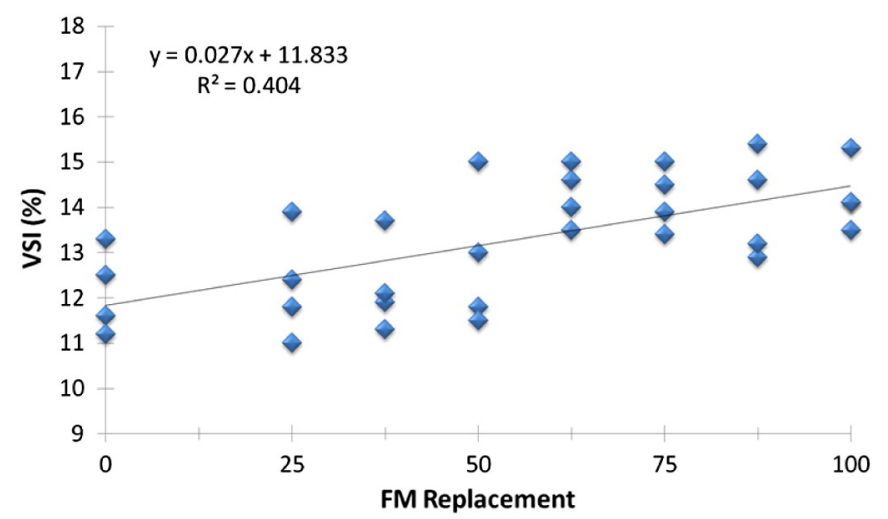

Fig. 5. Visceral somatic index (VSI) of fish fed diets with increasing levels of FM replacement by GDDY in the diet.
Table 6

Whole body proximate composition (wet weight basis) and nutrient retention efficiency of juvenile rainbow trout $(22.1 \pm 0.3 \mathrm{~g})$ fed test diets containing grain distillers dried yeast (GDDY) for 9 weeks. ${ }^{\text {a }}$

\begin{tabular}{llcllll}
\hline Diet $^{\mathrm{b}}$ & Moisture (\%) & Fat (\%) & Protein (\%) & $\begin{array}{l}\text { Energy } \\
(\mathrm{kcal} / \mathrm{g})\end{array}$ & PRE $^{\mathrm{c}}(\%)$ & ERE $^{\mathrm{d}}(\%)$ \\
\hline $0 \%$ & 67.5 & 13.5 & 17.0 & 2228 & 36.7 & 44.2 \\
$25 \%$ & 68.8 & 12.5 & 16.7 & 2171 & 37.1 & 43.6 \\
$37.5 \%$ & 67.7 & 13.2 & 16.7 & 2267 & 38.2 & 44.0 \\
$50 \%$ & 69.4 & 11.8 & 16.1 & 2087 & 32.9 & 40.1 \\
$62.5 \%$ & 68.3 & 12.6 & 17.1 & 2190 & 37.1 & 45.4 \\
$75 \%$ & 69.3 & 12.3 & 16.4 & 2179 & 36.5 & 42.8 \\
$87 \%$ & 68.4 & 12.6 & 16.8 & 2234 & 36.5 & 41.4 \\
$100 \%$ & 68.3 & 12.8 & 16.9 & 2215 & 38.2 & 39.6 \\
Pooled SE & 0.98 & 0.62 & 0.32 & 52.7 & 2.21 & 2.77 \\
$P r>$ F & 0.837 & 0.657 & 0.454 & 0.416 & 0.784 & 0.777 \\
\hline
\end{tabular}

a Mean determinations in three fish/tank from $N=4$ replicate tanks/diet.

b Percent of fish meal replaced by GDDY on a digestible protein basis.

c PRE, protein retention efficiency $=$ g protein gain $\times 100 / \mathrm{g}$ protein fed.

d ERE, energy retention efficiency $=$ kcal energy gain $\times 100 /$ kcal energy fed.

One explanation for a potential amino acid deficiency may be the presence of non-protein nitrogen present in GDDY in the form of the nucleic acids. Rumsey et al. (1991a, 1991b) reported that most BDY products were approximately $20-25 \%$ nucleic acid. Rainbow trout utilize nucleic acid nitrogen differently than they utilize nitrogen supplied from amino acids. In monogastric animals, nucleic acid content results in the formation of uric acid in the blood. Uric acid is further catabolized by the enzyme uricase into allatoin that is further degraded into urea and glyoxylic acid which are both excreted in the urine (Rumsey et al., 1991a,b). Although not analyzed in the current study, the presence of non-protein nitrogen in GDDY is also supported by a lower sum of amino acids in GDDY than the measured crude protein content. In the current study, crude protein digestibility was high at $98 \%$ relative to the total amino acid availability which was only $81 \%$. This difference is difficult to reconcile with the fact that we observed no differences in PRE and ERE when fish were fed treatment diets compared to the control, as one would have expected PRE to decrease if the amino acids were less digestible.

Concomitantly, the decreases in growth observed in the current study may be attributable to alterations in pellet quality. Although no major problems with breakage or fines were noted during the feeding trial a significant correlation between GDDY inclusion rate and pellet loss during Holman durability testing was observed. Previous authors have suggested that pellet quality alters rate of passage in rainbow trout (Aas et al., 2011), subsequently altering the trout's ability to utilize nutrients in the diet. These authors observed higher growth rates and increased feed intake potentially due to an increased rate of digestion in the diet with lower hardness and a larger percentage of broken pellets evaluated by DORIS analysis. Baeverfjord et al. (2006) evaluated the effects of feed pellet water stability on protein and fat digestibility with rainbow trout. In that trial, water stability did not affect protein digestibility but as water stability decreased the lipid digestibility tended to decline. Although in the current trial there appears to be a correlation between pellet durability and fish performance, insufficient data exist to clearly define this as the primary restriction to GDDY inclusion on trout performance.

Another potential concern, which has been raised in terms of alternative protein utilization, is the utilization of crystalline amino acids to balance nutritional needs. It has been demonstrated that crystalline amino acids are absorbed from the chyme at a higher rate than amino acids supplied as intact proteins, which could potentially create a time-based imbalance even though the diets were complete (Schuhmacher et al., 1997). Ok et al. (2001) observed a notably shorter time to postprandial peak in most plasma amino acid concentration of $4 \mathrm{~h}$ with rainbow trout. In order to overcome the potential limitation of variable amino acid absorption and availability timing in the current trial, 
Table 7

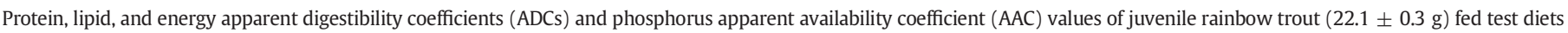
containing grain distillers dried yeast (GDDY) for 9 weeks. ${ }^{a}$

\begin{tabular}{|c|c|c|c|c|}
\hline \multirow[t]{2}{*}{ Diet $^{b}$} & Crude protein ADC & Crude lipid ADC & Gross energy ADC & Phosphorus AAC \\
\hline & \multicolumn{4}{|l|}{$\%$} \\
\hline $0 \%$ & $84.9^{c}$ & 87.9 & 81.2 & $31.4^{\mathrm{e}}$ \\
\hline $25 \%$ & $85.1^{\mathrm{b}, \mathrm{c}}$ & 86.4 & 80.6 & $37.1^{d}$ \\
\hline $37.5 \%$ & $85.6^{b, c}$ & 87.1 & 79.7 & $44.3^{\mathrm{b}, \mathrm{c}}$ \\
\hline $50 \%$ & $86.8^{\mathrm{a}, \mathrm{b}, \mathrm{c}}$ & 86.4 & 81.0 & $41.8^{\mathrm{c}, \mathrm{d}}$ \\
\hline $62.5 \%$ & $85.6^{\text {b, c }}$ & 84.3 & 77.9 & $44.3^{\mathrm{b}, \mathrm{c}}$ \\
\hline $75 \%$ & $87.0^{\mathrm{a}, \mathrm{b}}$ & 83.6 & 78.6 & $41.7^{\mathrm{c}, \mathrm{d}}$ \\
\hline $87.5 \%$ & $87.9^{\mathrm{a}}$ & 87.4 & 80.1 & $47.8^{\mathrm{a}, \mathrm{b}}$ \\
\hline $100 \%$ & $88.1^{\mathrm{a}}$ & 85.5 & 79.2 & $51.1^{\mathrm{a}}$ \\
\hline Pooled SE & 0.59 & 1.29 & 0.92 & 1.56 \\
\hline $\operatorname{Pr}>\mathrm{F}$ & 0.0062 & 0.3467 & 0.2608 & $<0.0001$ \\
\hline
\end{tabular}

a Mean determinations in three fish/tank from $N=4$ replicate tanks/diet.

b Percent of fish meal replaced by GDDY on a digestible protein basis.

multiple feedings $(2 \times /$ day) were utilized to minimize any unequal absorption effects. The efficient utilization of crystalline amino acids in trout diets has been previously demonstrated by Gaylord and Barrows (2009). In that trial, with the exception of lysine which was postulated to be supplemented in excess, amino acid retention efficiencies of supplemental methionine and threonine were equal to efficiencies from the intact protein diets.

\section{Conclusions}

Based on the digestibility data, nutrients from GDDY were well digested and absorbed by rainbow trout, yet feeding high levels of GDDY resulted in linear reductions in performance and poorer FCRs. However, these performance factors were not associated with reductions in palatability because fish consumed equivalent amounts of the diets that contained higher inclusion levels of GDDY. Protein digestibilities among diets were essentially equal and all diets were balanced for available methionine, lysine, threonine and phosphorus. Hence, the reduced performance could not be attributed to any of these factors. The factors contributing to the reduced fish performance when 34\% (based on FCR) or $40 \%$ (based on growth) of the fish meal protein was replaced with GDDY protein are not clear at this point but may be attributable to another limiting amino acid or unknown interactive effect of the high nucleic acid or polysaccharide content of GDDY.

\section{Acknowledgments}

The authors would like to thank numerous individuals that made completion of this project possible: Christopher Hooley, Aaron Nistler, Eli Cureton, Matt Toner, Cal Fraser, and Jason Ilgen with the US Fish and Wildlife Service, Bozeman Fish Technology Center and Jason Frost with the USDA-ARS Trout Grains Project in Bozeman Montana. Mention of trade names or commercial products in this article is solely for the purpose of providing specific information and does not imply recommendation or endorsement by the US Fish and Wildlife Service or the United States Department of Agriculture (USDA).

\section{References}

Aas, T.S., Terjesen, B.F., Sigholt, T., Hillestad, M., Holm, J., Refstie, S., Baeverfjord, G., Rorvik, K.A., Sorensen, M., Maikeoehme, M., Asgard, T., 2011. Nutritional responses in rainbow trout (Oncorhynchus mykiss) fed diets with different physical qualities at stable or variable environmental conditions. Aquac. Nutr. 17, 657-670.

Anderson, K.A., 1996. Micro-digestion and ICP-AES analysis for the determination of macro and micro elements in plant tissues. At. Spectrosc. 17, 30-33.

AOAC, 1995. Official Methods of Analysis. Association of Official Analytical Chemists, Inc., Arlington, VA, USA.

Austreng, E., 1978. Digestibility determination in fish using chromic oxide marking and analysis of contents from different segments of the gastrointestinal tract. Aquaculture $13,265-272$.
Baeverfjord, G., Reftsie, S., Krogedal, A., Asgard, T., 2006. Low feed pellet water stability and fluctuating water salinity cause separation and accumulation of dietary oil in the stomach of rainbow trout (Oncorhynchus mykiss). Aquaculture 261, 1335-1345.

Barnes, M.E., Brown, M.L., Rosentrater, K.A., 2012a. Juvenile rainbow trout responses to diets containing distillers dried grain with solubles, phytase, and amino acid supplements. Open Int. J. Anim. Sci. 2, 69-77.

Barnes, M.E., Brown, M.L., Rosentrater, K.A., 2012b. Initial observations on the inclusion of high protein distillers dried grain into rainbow trout diets. Open Fish Sci. J. 5, 21-29.

Barrows, F.T., Gaylord, T.G., Sealey, W.M., Haas, M.J., Stroup, R.L., 2008. Processing soybean meal for biodiesel production; effect of a new processing method on growth performance of rainbow trout, Oncorhynchus mykiss. Aquaculture 283, 143-147.

Barrows, F.T., Gaylord, T.G., Sealey, W.M., Rawles, S.D., 2011. Database of Nutrient Digestiblity's of Traditional and Novel Feed Ingredients for Trout and Hybrid Striped Bass. USDA-ARS (Accessed at http://www.ars.usda.gov/Main/docs.htm?docid= 21905).

Bureau, D.P., Harris, A.M., Cho, C.Y., 1999. Apparent digestibility of rendered animal protein ingredients for rainbow trout (Oncorhynchus mykiss). Aquaculture 180, 345-358.

Cheng, Z.J., Hardy, R.W., 2004. Nutritional value of diets containing distiller's dried grain with solubles for rainbow trout, Oncorhynchus mykiss. J. Appl. Aquac. 15, 101-113.

Cho, C.Y., Slinger, S.J., Bayley, H.S., 1982. Bioenergetics of salmonid fishes: energy intake, expenditure and productivity. Comp. Biochem. Physiol. 73B, 25-41.

Craig, S.R., McLean, E., 2005. The organic aquaculture movement: a role for NuPro as an alternative protein source. In: Jacques, K., Lyons, P. (Eds.), Nutritional Biotechnology in the Food and Feed Industry. Nottingham University Press, UK.

Forster, I., 1999. A note on the method of calculating digestibility coefficients of nutrients provided by single ingredients to feeds of aquatic animals. Aquac. Nutr. 5, 143-145.

Freund, R.J., Littell, R.C., 2000. SAS® System for Regression, Third edition. SAS Institute Inc. , Cary, NC, USA.

Gatesoupe, F.J., 2007. Live yeasts in the gut: natural occurrence, dietary introduction, and their effects on fish health and development. Aquaculture 267, 20-30.

Gatlin, D.M., Barrows, FT., Bellis, D., Brown, P., Campen, J., Dabrowski, K., Gaylord, T.G., Hardy, R.W., Herman, E., Hu, G., Krogdahl, A., Nelson, R., Overturf, K., Rust, M., Sealey, W., Skonberg, D., Souza, E., Stone, D., Wilson, R., Wurtele, E., 2007. Expanding the utilization of sustainable plant products in aquafeeds - a review. Aquac. Res. 38, 551-579.

Gause, B., Trushenski, J., 2011a. Replacement of fish meal with EY in the diets of sunshine bass. N. Am. J. Aquac. 73, 97-103.

Gause, B., Trushenski, J., 2011b. Production performance and stress tolerance of sunshine bass raised on reduced fish meal feeds containing EY. N. Am. J. Aquac. 73, 168-175.

Gaylord, T.G., Barrows, F.T., Rawles, S.D., 2008. Apparent digestibility of gross nutrients from feedstuffs in extruded feed diets for rainbow trout, Oncorhynchus mykiss. J. World Aquacult. Soc. 39, 827-834.

Gaylord, T.G., Barrows, F.T., 2009. Multiple amino acid supplementations to reduce dietary protein in plant-based rainbow trout, Oncorhynchus mykiss, feeds. Aquaculture 287, 180-184.

Gaylord, T.G., Barrows, F.T., Rawles, S.D., 2010. Apparent amino acid availability from feedstuffs in extruded diets for rainbow trout, Oncorhynchus mykiss. Aquac. Nutr. $16,400-406$

Kleiber, M., 1961. The Fire of Life: An Introduction to Animal Energetics. John Wiley and Sons, Inc., New York, NY, USA.

Kramer, C.Y., 1956. Extension of multiple range tests to group means with unequal numbers of replications. Biometrics 12, 307-310.

Lunger, A.N., Craig, S.R., McLean, E., 2006. Replacement of fish meal in cobia (Rachycentron canadum) diets using an organically certified protein. Aquaculture 257, 393-399.

Martin, A.M., Goddard, S., Bemistera, P., 1993. Production of Candida utilis biomass as aquaculture feed. J. Sci. Food Agric. 61, 363-370.

National Research Council (NRC), 2011. Nutrient Requirements of Fish. National Academy Press, Washington.

Ok, I.H., Bai, S.C., Park, G.J., Choi, S.M., Kim, K.W., 2001. The patterns of plasma free amino acids after force-feeding in rainbow trout Oncorhynchus mykiss (Walbaum) with and without dorsal aorta cannulation. Aquac. Res. 32, 70-75.

Øverland, M., Krogdahl, A., Shurson, G., Skrede, A., Denstadli, V., 2013. Evaluation of distiller's dried grains with solubles (DDGS) and high protein distiller's dried grains (HPDDG) in diets for rainbow trout (Oncorhynchus mykiss). Aquaculture 416, 201-208. 
Rumsey, G.L., Hughes, S.G., Smith, R.R., Kinsella, J.E., Shetty, K.J., 1991a. Digestibility and energy values of intact, disrupted and extracts from brewer's dried yeast fed to rainbow trout (Oncorhynchus mykiss). Anim. Feed Sci. Technol. 33, 185-193.

Rumsey, G.L., Kinsella, J.E., Shetty, K.J., Hughes, S.G., 1991b. Effect of high dietary concentrations of brewer's dried yeast on growth performance and liver uricase in rainbow trout (Oncorhynchus mykiss). Anim. Feed Sci. Technol. 33, 177-183.

Schuhmacher, A., Wax, C., Gropp, J.M., 1997. Plasma amino acids in rainbow trout (Oncorhynchus mykiss) fed intact protein or crystalline amino acid diet. Aquaculture $151,15-28$.
Snyder, G.S., Gaylord, T.G., Barrows, F.T., Overturf, K., Cain, K.D., Hill, R.A., Hardy, R.W. 2012. Effects of carnosine supplementation to an all-plant protein diet for rainbow trout (Oncorhynchus mykiss). Aquaculture 338-341, 72-81.

Tacon, A.G.J., Metian, M., 2008. Global overview on the use of fish meal and fish oil in industrially compounded aquafeeds: trends and future prospects. Aquaculture 285, $146-158$.

Tukey, J.W., 1953. The problem of multiple comparisons. Unpublished manuscript. Princeton University, Princeton, New Jersey, USA 